\title{
Microwave assisted extraction of phytochemicals from bark of Cassia occidentalis $\mathbf{L}$.
}

Sumera Javad*, Shabnam Shaheen, Farah Khan and Sidra Younis

Department of Botany Lahore College for Women University, Lahore, Pakistan

*Corresponding author's email: zif_4@yahoo.com

Citation

Sumera Javad, Shabnam Shaheen, Farah Khan and Sidra Younis. Microwave assisted extraction of phytochemicals from bark of Cassia occidentalis L. Pure and Applied Biology. Vol. 5, Issue 1, 2016, pp48-57. http://dx.doi.org/10.19045/bspab.2016.50007

\begin{tabular}{llll}
\hline \hline Received: 05/10/2015 & Revised: 07/12/2015 & Accepted: 15/12/2015 & Online First: 19/12/2015 \\
\hline \hline
\end{tabular}

\section{Abstract}

Microwave assisted extraction is a modern and new approach for rapid and efficient extraction of plant material which are rich in number of secondary metabolites of prime importance. In present study a comparison was made between conventional method of extraction i.e., Soxhlet extraction, and modern method of extraction i.e., Microwave assisted extraction for the rapid and efficient extraction of Cassia occidentalis L. bark. Microwave assisted extraction was proved to be more rapid and more efficient for extraction of bark of Cassia occidentalis which yielded 190mg of extract/ $1 \mathrm{~g}$ of bark powder in 70 seconds of microwave irradiation of $700 \mathrm{~W}$ as compared to $160 \mathrm{mg}$ of extract $/ 30 \mathrm{~g}$ or $5.33 \mathrm{mg}$ of extract per gram of bark powder in 15 hours of continuous heating of the soxhlet extraction. It was also observed that a maximum of $170.87 \mu \mathrm{g}$ equivalent of Gallic acid of phenolics were obtained from extract of Microwave heating (900W) for 30 seconds while 177 $\mu \mathrm{g}$ equivalent of Catechin of flavonoids were obtained from a microwave assisted extract at 70 seconds of $900 \mathrm{~W}$ of irradiation. In contrast, soxhlet extraction produced only $96.75 \mu \mathrm{g}$ equivalent of Gallic acid and $120 \mu \mathrm{g}$ equivalent of Catechin after 15 and 10 hours of extraction respectively. Furthermore higher amount of alkaloids were obtained from microwave assisted extraction (3.2 mg eq of Dragondroff reagent). So it was proved that microwave assisted extraction was efficient as well as cost effective in terms of lesser use of energy, time and solvent.

Key words: Microwave assisted extraction; Cassia occidentalis; Bark; Phenolics; Flavonoids; Microwaves.

Introduction

Microorganisms with developed drug resistance are a great source of threat for human beings. When antibiotics were discovered, number and intensity of diseases decreased and their use in different fields like food, dentistry, medicine and agriculture increased rapidly. But with the passage of time due to over use and misuse of antibiotics, pathogens evolved with more resistance towards discovered and formulated antibiotics. Examples of such organisms are strains of Salmonella enterica, Escherichia coli, Mycobacterium tuberculosis, Staphylococcus aureus, Xanthomonas and Pseudomonas aeruginosa [1-3].

Due to all above discussed reasons, use of natural bioactive components has become very common and started to increase rapidly 
e.g., natural bioactive components of plant extracts. People are now more intended towards herbal medicines. Sources of these natural compounds are usually easily available in surrounding and easy to select on the basis of experience of common man [4]. In this regard a number of plant based drugs are in use e.g., digitoxin from foxglove, Vinblastine from Catharanthus, morphine from the opium poppy, quinine from cinchona bark and aspirin from willow bark [5].

Pakistan has a variety of medicinal plants. People living in villages and valleys use indigenous plants of their local areas to cure a number of ailments like asthma, blood pressure, fever, snake bite, diarrhea, jaundice, cough, abdominal pain, eye and kidney infections etc $[6,7]$.

One of these medicinal plants is Cassia occidentalis Linn. (Known as Kasondi) belonging to family Fabaceae and Subfamily Caesalpinioideae and it is very commonly distributed in tropical and warm temperate regions of the world. The plant is 6-8 feet in height. Its roasted seeds are used as coffee giving the idea of its use as functional food (Used as food as well as medicine). Its leaves are also cooked and eaten. Its medicinal value is also valid and reported. Its leaves, seeds and roots are used to cure fever, asthma, tuberculosis, liver problems, kidney problems, menstrual cycle problems etc. particularly its leaves have very prominent antiplasmodial, antimalarial, antimutagenic, antibacterial and anticarcinogenic activity $[8$, 9].

But to observe all of these activities, extraction is first and essential step to get important phytochemicals from plants. But in our local herbal industry, it's the forbidden step. Extraction in our local industry usually depends upon the common and conventional methods of extraction which produce lesser products and consume more energy. So it is the requirement to optimize some modern methods to get targeted phytochemicals from selected plants in lesser time frame as well as little use of energy and solvents $[10,11]$. One of such modern methods is microwave assisted extraction.

Microwaves are non-ionizing and do not change the structure of targeted molecule. They are considered as safe for extracting natural products. A lot of research work has been done to evaluate the Microwave assisted extraction for extraction of phytoconstituents, but unluckily, there is no work still reported for microwave assisted extraction of Cassia occidentalis. So in the present study, Microwave assisted extraction and soxhlet extraction have been done and compared for efficacy for production of extracts, phenolics, flavonoids and alkaloids.

\section{Materials and Methods}

The description of plant was confirmed by different flora $[12,13]$. Plant material (bark of Cassia occidentalis) was collected from Jinnah Garden Lahore. Herbarium specimen was prepared and placed in Herbarium of Lahore College for Women University, Lahore, Pakistan. Bark was air dried, finely powdered and stored in air tight jars. Microwave assisted extraction in present study was carried out on Haier microwave (HGN-45100EB). Parameters studied were power level (300, 500, 700 and $900 \mathrm{~W})$, time $(10,20,30, \ldots, 100$ seconds), solvent type (Ethanol, Water and n-hexane) and solvent quantity (5-15ml). Each time $1 \mathrm{~g}$ plant material was taken. For soxhlet extraction parameters optimized were time of extraction (5, 10, 15 and 20 hours), Solvent type (Ethanol, Water, n-hexane) and quantity of solvent (150, 200, 250 and $300 \mathrm{~mL})$. Each time 30 grams of plant sample was taken. After that percentage of extract was determined and each extract was quantified for phenolics, flavonoids and alkaloids.

\section{Estimation of Phenolics}

Spectrophotometric assay was used to estimate phenolics in the extract [14]. Each time $1 \mathrm{ml}$ of sample $(1 \mathrm{mg} / 1 \mathrm{ml})+1 \mathrm{ml}$ of 
Folinand Ciocalteu's phenol reagent was mixed and left to stay for 3 minutes, followed by the addition of $1 \mathrm{ml}$ of saturated $\mathrm{Na}_{2} \mathrm{CO}_{3}$ and total volume was raised up to $10 \mathrm{ml}$ by distilled water. Reaction mixture was kept in dark for 1.5 hours and then absorbance was checked at $725 \mathrm{~nm}$. Standard curve of Gallic acid (Fig. 1) was constructed by using dilutions of Gallic acid. Phenolics were represented as $\mu \mathrm{g}$ eq of Gallic acid.

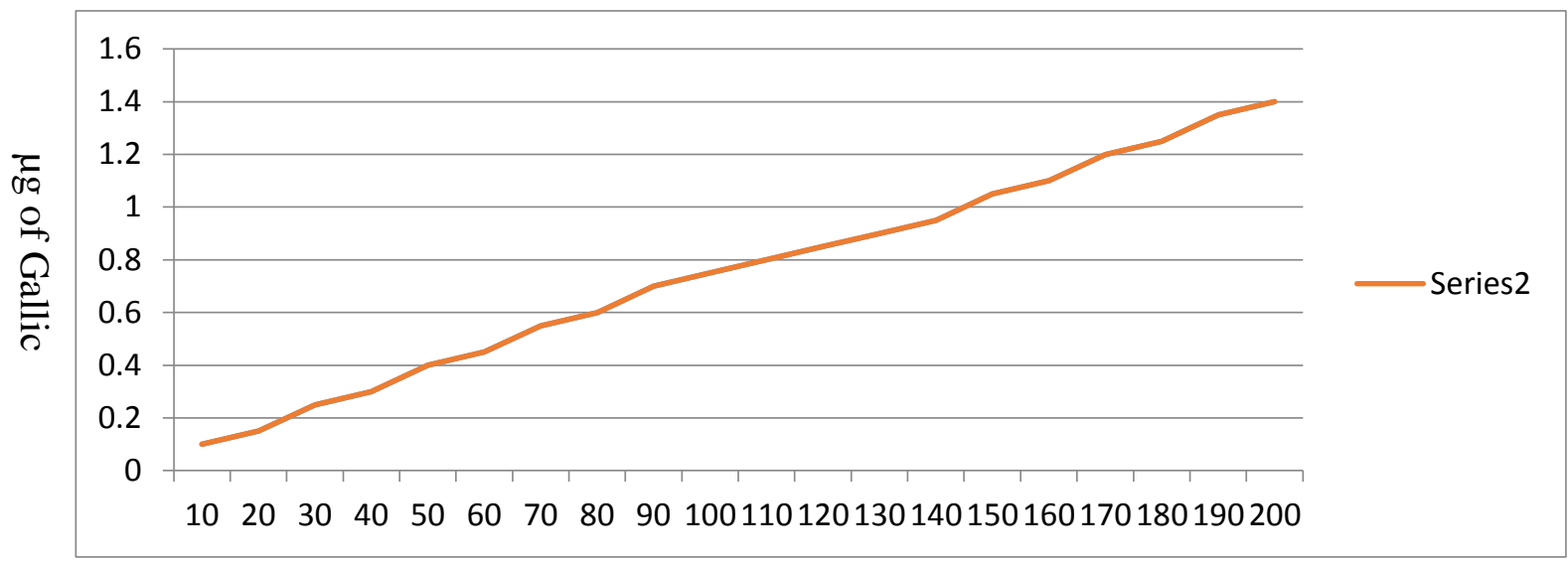

Figure 1. Standard absorption graph of Gallic acid

\section{Estimation of flavonoids}

Flavonoids present in the extracts were also determined by Spectrophotometric method [15]. In this method, $1 \mathrm{ml}$ of sample $(1 \mathrm{mg} / \mathrm{ml})$ was mixed with $5 \mathrm{ml}$ of distilled water and $0.3 \mathrm{ml}$ of $5 \%$ sodium nitrite and $0.6 \mathrm{ml}$ of aluminum chloride was added and reaction mixture was allowed to stand for 6 minutes. After that $1.5 \mathrm{ml}$ off distilled water and $2 \mathrm{ml}$ of $1 \mathrm{M} \mathrm{NaOH}$ were added and after thorough mixing, absorbance was checked at 510nm, where Catechin was used as a standard (Fig. 2).

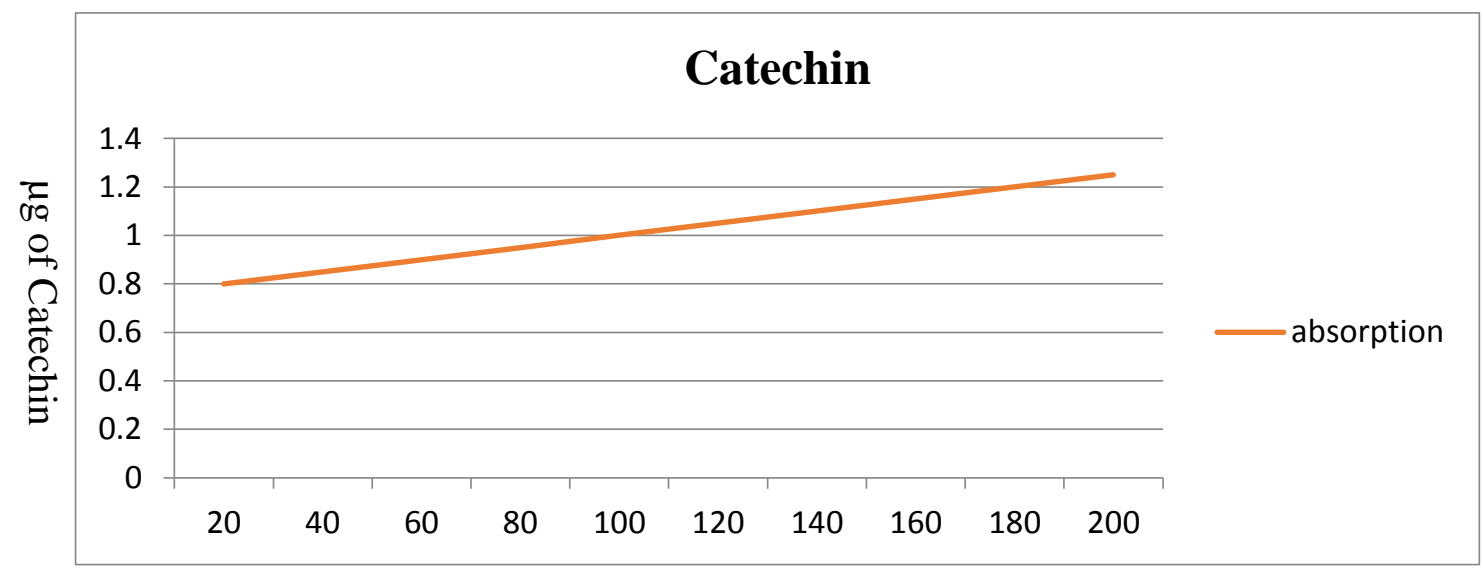

Figure 2. Standard absorption graph of Catechin 


\section{Estimation of Alkaloids}

Spectrophotometric method was also used to study the alkaloid content of extract [16]. For this purpose, $0.5 \mathrm{~g}$ of extract $+1 \mathrm{ml}$ of ethanol $+2 \mathrm{ml}$ of Dragon Droff reagent were mixed well. Precipitates formed were dissolved in $0.5 \mathrm{ml}$ of disodium sulphide with 2-3 drops of conc. Nitric acid. Brown ppts formed were mixed in $2 \mathrm{ml}$ of Thiourea and absorbance was checked at $435 \mathrm{~nm}$.
Dragondroff's reagent was used to calculate the standard curve and the results were expressed as $\mathrm{mL}$ of Dragondroff's equivalents (DEs) per mg of extract (Fig 3).

The data produced from all above experiments was analyzed by applying ANOVA and Duncan's multiple range test at $5 \%$ level of significance using COSTAT computer software.

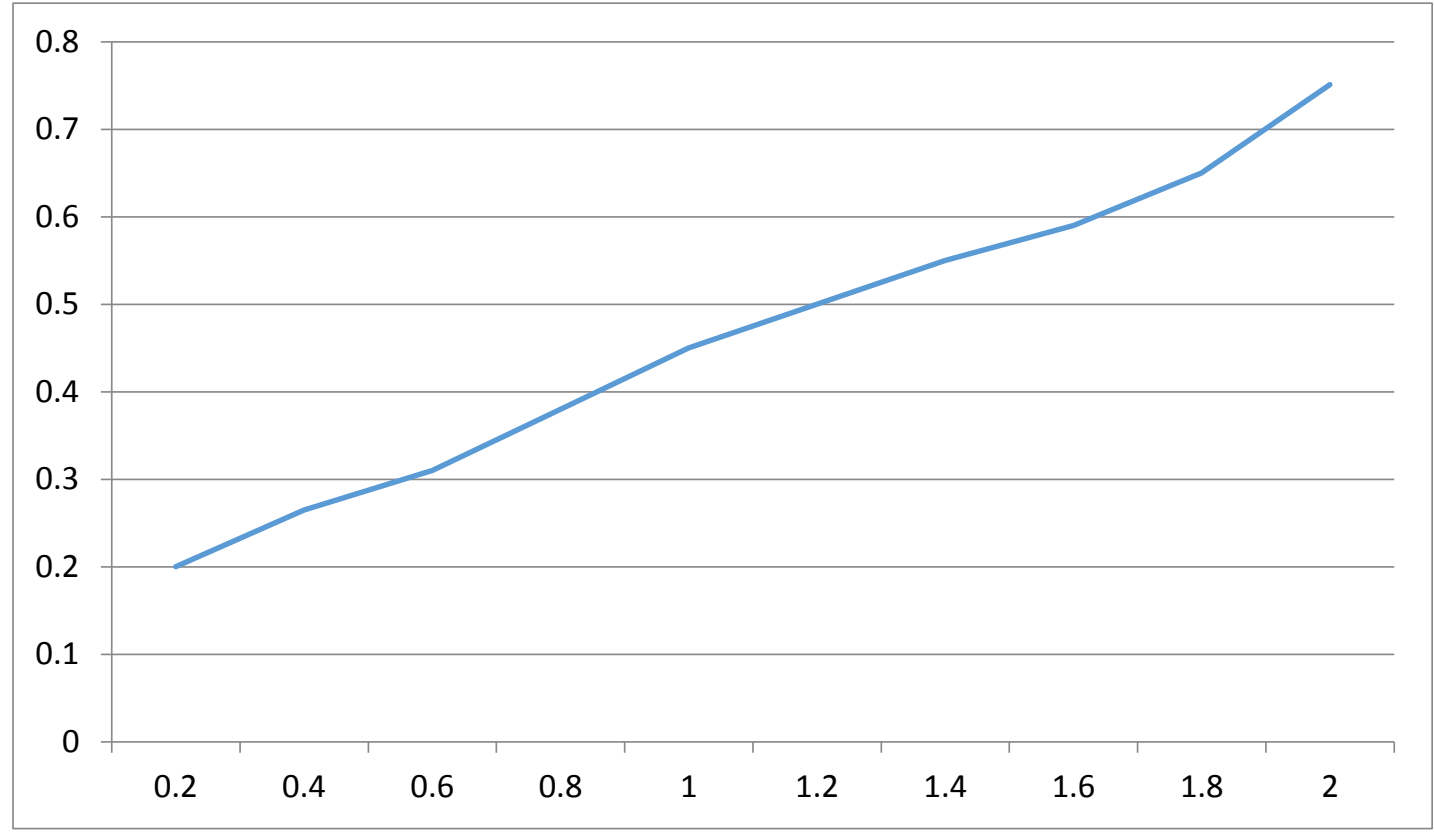

Figure 3. Standard absorption graph of Dragondroff reagent

In present research work, microwave assisted extraction and Soxhlet extraction of Cassia occidentalis L (bark powder) was done followed by estimation of phenolics, flavonoids and alkaloids. There was no significant effect of timing on MAE at power level $300 \mathrm{~W}$. The highest amount of extraction was 140,190 and $170 \mathrm{mg}$ per gram of plant material at power levels $500 \mathrm{~W}, 700$ $\mathrm{W}$ and $900 \mathrm{~W}$ respectively; and timings optimized were 70,70 and 30 seconds, respectively. Results prominently showed that on increasing the power level from 500$700 \mathrm{~W}$, amount of extract started to increase (Table 1); while a further increase in the power level, extract started to decrease. In the present research work, effect of solvent nature on extraction was also studied and results showed that ethanol has greater capability of extraction from Cassia occidentalis' bark powder as compared to water and hexane, at all power levels i.e., 300,500 and $900 \mathrm{~W}$, maximum extract was obtained from ethanol (Fig 4).

While $10 \mathrm{~mL} / \mathrm{g}$ of solvent was optimized quantity for optimum microwave assisted extraction of Cassia occidentalis.

Jaitaket al., 2009 and Javad et al., 2014 obtained higher amounts of stevioside from microwave assisted extraction of Stevia rebaudiana in a lower power level and higher timing combination $[17,18]$. Higher amounts 
of curcumin have also been reported by Mandal et al., 2008 from microwave assisted extraction of Curcuma longa L. They were also in the favor of low power and higher time of microwaves irradiation [19]. Almost similar results were presented by Shu et al., 2003 by microwave assisted extraction of ginseng roots [20]. Microwave assisted extraction is mainly affected by two factors i.e., power level of microwaves and time of irradiation. These two factors have proven effect on the final product of microwave assisted extraction of bioactive components. High time to low power combination is an often used protocol for optimizing extraction of any compound using microwave assisted extraction because higher energy levels increase kinetic energies up to the level where extract may be burnt and similarly longer exposures to microwaves can also damage the molecules [21].

Table 1. Optimization of time and power level of microwave assisted extraction from bark of Cassia occidentalis

\begin{tabular}{|c|c|c|c|c|c|}
\hline \multirow{2}{*}{ Sr. \# } & $\begin{array}{c}\text { Time of } \\
\text { Extraction } \\
(\mathbf{s e c})\end{array}$ & $\mathbf{3 0 0} \mathbf{W}$ & $\mathbf{3}$ & \multicolumn{3}{|c|}{ Extraction from bark of Cassia occidentalis in microwaves } \\
\cline { 3 - 6 } & $\mathbf{1 0}$ & $70^{\mathrm{cd}} \pm 4.00$ & $70^{\mathrm{d}} \pm 7.00$ & $70^{\mathrm{h}} \pm 4.00$ & $\mathbf{9 0 0 \mathbf { W }}$ \\
\hline $\mathbf{1}$ & $\mathbf{2 0}$ & $80^{\mathrm{c}} \pm 5.00$ & $90^{\mathrm{c}} \pm 1.00$ & $130^{\mathrm{e}} \pm 1.00$ & $130^{\mathrm{b}} \pm 2.0$ \\
\hline $\mathbf{2}$ & $\mathbf{3 0}$ & $88^{\mathrm{c}} \pm 1.0$ & $110^{\mathrm{b}} \pm 3.00$ & $140^{\mathrm{d}} \pm 3.00$ & $130^{\mathrm{b}} \pm 2.0$ \\
\hline $\mathbf{3}$ & $\mathbf{3 0}$ & $100^{\mathrm{ab}} \pm 1.0$ & $100^{\mathrm{b}} \pm 2.00$ & $150^{\mathrm{c}} \pm 5.00$ & $130^{\mathrm{b}} \pm 3.0$ \\
\hline $\mathbf{4}$ & $\mathbf{5 0}$ & $100^{\mathrm{ab}} \pm 3.0$ & $100^{\mathrm{b}} \pm 4.00$ & $140^{\mathrm{d}} \pm 2.00$ & $120^{\mathrm{c}} \pm 1.0$ \\
\hline $\mathbf{5}$ & $\mathbf{6 0}$ & $102^{\mathrm{ab}} \pm 1.0$ & $100^{\mathrm{b}} \pm 1.00$ & $160^{\mathrm{b}} \pm 2.00$ & $10^{\mathrm{d}} \pm 1.0$ \\
\hline $\mathbf{6}$ & $\mathbf{7 0}$ & $102^{\mathrm{ab}} \pm 0.09$ & $140^{\mathrm{a}} \pm 1.00$ & $190^{\mathrm{a}} \pm 2.00$ & $10^{\mathrm{d}} \pm 4.0$ \\
\hline $\mathbf{7}$ & $\mathbf{8 0}$ & $110^{\mathrm{a}} \pm 1.0$ & $80^{\mathrm{c}} \pm 9.00$ & $110^{\mathrm{g}} \pm 3.00$ & $80^{\mathrm{e}} \pm 3.0$ \\
\hline $\mathbf{8}$ & $\mathbf{9 0}$ & $110^{\mathrm{a}} \pm 1.00$ & $80^{\mathrm{c}} \pm 1.00$ & $130^{\mathrm{e}} \pm 1.00$ & $60^{\mathrm{e}} \pm 4.0$ \\
\hline $\mathbf{9}$ & $\mathbf{1 0 0}$ & $110^{\mathrm{a}} \pm 4.00$ & $60^{\mathrm{d}} \pm 3.00$ & $120^{\mathrm{f}} \pm 1.00$ & $60^{\mathrm{e}} \pm 1.0$ \\
\hline $\mathbf{1 0}$ & &
\end{tabular}

Each value is mean of five replicate with standard error (mean $\pm \mathrm{S}$. E). Means within a column not sharing a common superscript differ significantly $(\mathrm{P}<0.05)$ according to Duncan's new multiple range test

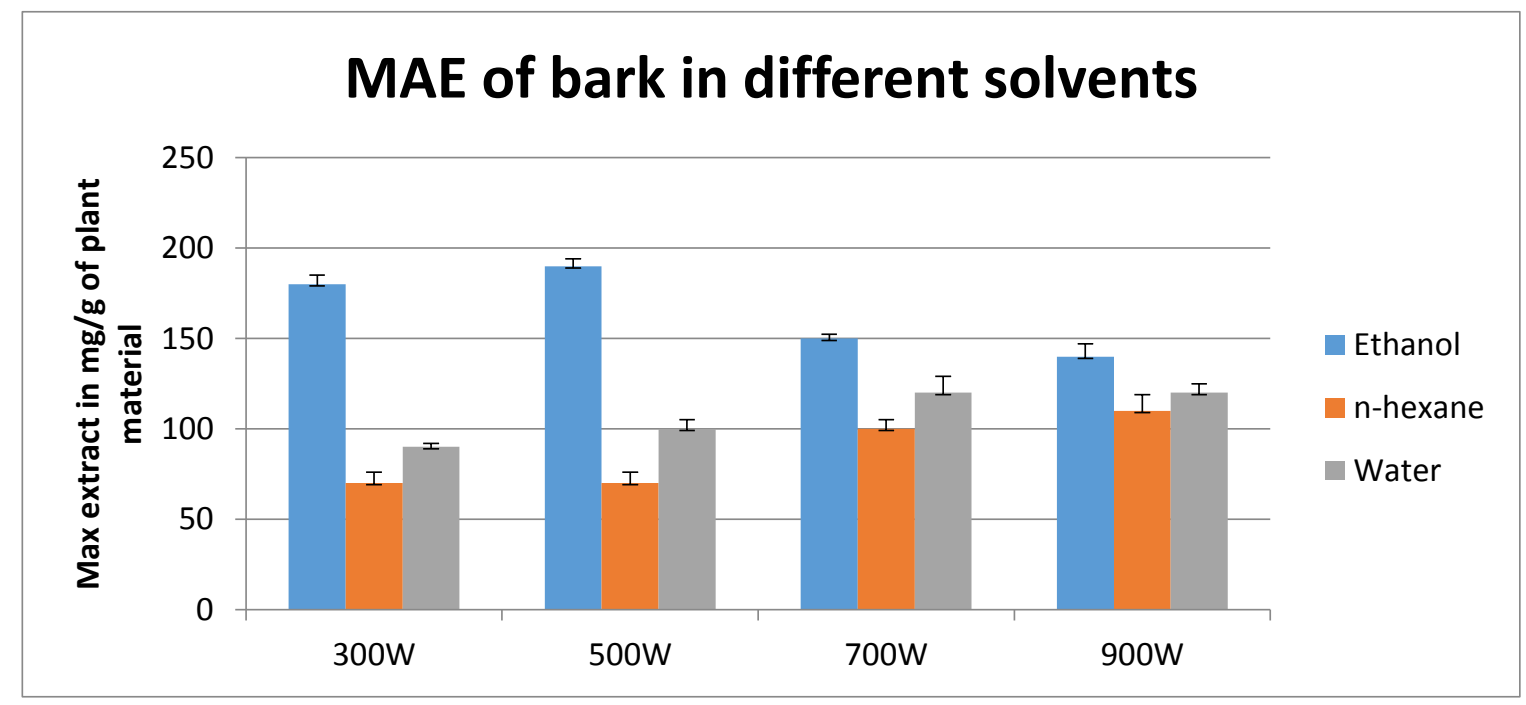

Figure 4: Effect of solvent nature on microwave assisted extraction of Cassia occidentalis L. 
Present study also showed that soxhlet extraction produced only $160 \mathrm{mg}$ of extract per 30 gram or $5.33 \mathrm{mg}$ per gram of plant material after 15 hours of extraction from ethanol (Table 2). Figure 5 shows the efficiency of ethanol for soxhlet extraction of Cassia occidentalis L. Soxhlet extractions usually take longer times to accomplish; this may be due to static condition of plant material which means there is no agitation. Agitation basically provides more exposure of the matrix and extracting solvent which in turn leads towards the breakage of more bonds and release of more products in the environment. Narrow position of plant material in the thimble of soxhlet extractor is another reason which decreases the chances of complete contact of the solvent and the plant sample. Due to longer time of extraction there is increased evaporation of solvent, so consumption of solvent is increased along with the heating energy. Longer heating times also destroy chemical components of the extract [22].

Table 2. Optimization of time of soxhlet extraction from bark of Cassia occidentalis

\begin{tabular}{|c|c|c|c|}
\hline \multirow{2}{*}{ Sr. \# } & $\begin{array}{c}\text { Time of extraction } \\
\text { Hours }\end{array}$ & & \multicolumn{2}{|c|}{ Amount of extract } \\
\cline { 2 - 4 } & 5 & $\mathbf{m g} / 30 \mathrm{~g}$ & $\mathbf{m g} / \mathbf{g}$ \\
\hline 1 & 10 & $120^{\mathrm{c}} \pm 3.37$ & $4.00^{\mathrm{c}} \pm 1.12$ \\
\hline 2 & 15 & $131^{\mathrm{b}} \pm 8.43$ & $4.33^{\mathrm{b}} \pm 2.47$ \\
\hline 3 & 20 & $160^{\mathrm{a}} \pm 4.51$ & $5.33^{\mathrm{a}} \pm 1.50$ \\
\hline 4 & $110^{\mathrm{d}} \pm 3.81$ & $3.33^{\mathrm{d}} \pm 1.27$ \\
\hline
\end{tabular}

Each value is mean of five replicate with standard error (mean $\pm \mathrm{S}$. E). Means within a column not sharing a common superscript differ significantly $(\mathrm{P}<0.05)$ according to Duncan's new multiple range test

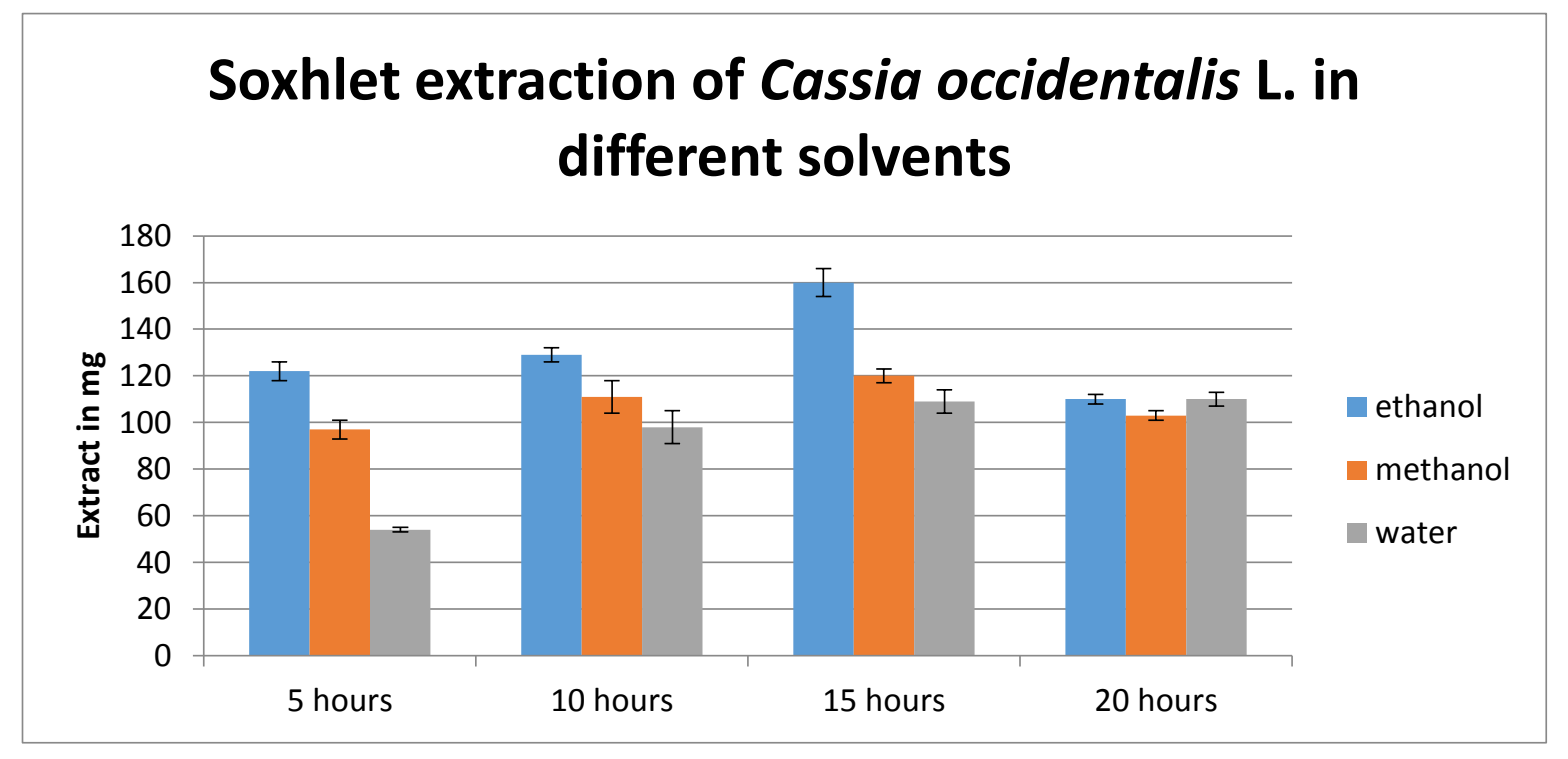

Figure 5. Effect of solvent nature on soxhlet extraction of Bark of Cassia occidentalis $L$. 
Soxhlet extractions usually take longer times to accomplish; this may be due to static condition of plant material which means there is no agitation. Agitation basically provides more exposure of the matrix and extracting solvent which in turn leads towards the breakage of more bonds and release of more products in the environment. Narrow position of plant material in the thimble of soxhlet extractor is another reason which decreases the chances of complete contact of the solvent and the plant sample. Due to longer time of extraction there is increased evaporation of solvent, so consumption of solvent is increased along with the heating energy. Longer heating times also destroy chemical components of the extract [22].

Present study also revealed higher amounts of phenolics (170 $\mu \mathrm{g}$ eq. of Gallic acid), flavonoids (177 $\mu \mathrm{g}$ eq. of Catechin) and alkaloids (3.1 $\mu \mathrm{g}$ equivalent of Dragondroff) in microwave assisted extraction (Table 3)as compared to soxhlet extraction $(97 \mu \mathrm{g}$ eq. of Gallic acid, $118 \mu \mathrm{g}$ eq. of Catechin and $1.6 \mu \mathrm{g}$ equivalent of Dragondroff), respectively (Table 4). When amount of these phytochemical was compared, it was found that amount of phenolics, flavonoids and alkaloids were higher in microwave assisted extraction as compared to extracts of soxhlet extraction (Table 4).

Table 3. Estimation of phytochemical in microwave assisted extracts of Cassia occidentalis

\begin{tabular}{|c|c|c|c|c|c|}
\hline $\begin{array}{c}\mathbf{S r} \\
\#\end{array}$ & $\begin{array}{c}\text { Power } \\
\text { level }(W)\end{array}$ & $\begin{array}{l}\text { Time } \\
\text { (sec) }\end{array}$ & $\begin{array}{c}\text { Phenolics } \\
\text { ( } \mu \text { g equivalent } \\
\text { of Gallic acid) }\end{array}$ & $\begin{array}{c}\text { Flavonoids } \\
\text { ( } \mu \text { g equivalent } \\
\text { of Catechin) }\end{array}$ & $\begin{array}{c}\text { Alkaloids } \\
\text { (mg equivalent of } \\
\text { Dragondroff reagent) }\end{array}$ \\
\hline \multirow[t]{6}{*}{1} & \multirow[t]{6}{*}{500} & 10 & $51.65^{\mathrm{h}} \pm 1.00$ & $48.0 \pm 2.11$ & $0.6^{\mathrm{fg}} \pm 0.03$ \\
\hline & & 30 & $20.37^{\mathrm{j}} \pm 2.33$ & $120^{\mathrm{e}} \pm 0.39$ & $0.4^{\mathrm{g}} \pm 0.09$ \\
\hline & & 50 & $102.62^{\mathrm{g}} \pm 9.02$ & $141^{\mathrm{e}} \pm 2.47$ & $0.7^{\mathrm{f}} \pm 0.001$ \\
\hline & & 70 & $67.75^{\mathrm{h}} \pm 4.31$ & $88^{\mathrm{g}} \pm 1.98$ & $0.35^{\mathrm{g}} \pm 0.01$ \\
\hline & & 90 & $55.75^{\mathrm{h}} \pm 1.04$ & $48^{\mathrm{h}} \pm 4.09$ & $0.25^{\mathrm{g}} \pm 0.05$ \\
\hline & & 100 & $49.00^{i} \pm 3.34$ & $93^{\mathrm{g}} \pm 3.33$ & $0.25^{\mathrm{g}} \pm 0.05$ \\
\hline \multirow[t]{6}{*}{2} & \multirow[t]{6}{*}{700} & 10 & $116.12^{f} \pm 1.76$ & $103^{\mathrm{f}} \pm 3.09$ & $1.1^{\mathrm{e}} \pm 0.05$ \\
\hline & & 30 & $141.37^{c} \pm 1.39$ & $140^{\mathrm{d}} \pm 8.09$ & $1.25^{\mathrm{e}} \pm 0.01$ \\
\hline & & 50 & $137.62^{\mathrm{d}} \pm 5.34$ & $171^{\mathrm{b}} \pm 2.53$ & $1.7^{\mathrm{d}} \pm 0.03$ \\
\hline & & 70 & $139.12^{\mathrm{cd}} \pm 4.69$ & $160^{c} \pm 8.65$ & $2.2^{\mathrm{c}} \pm 0.09$ \\
\hline & & 90 & $125.00^{\mathrm{e}} \pm 3.28$ & $110^{\mathrm{f}} \pm 2.74$ & $1.55^{\mathrm{e}} \pm 0.01$ \\
\hline & & 100 & $118.18^{\mathrm{f}} \pm 6.66$ & $105^{\mathrm{f}} \pm 1.09$ & $0.8^{\mathrm{f}} \pm 0.02$ \\
\hline \multirow[t]{6}{*}{3} & \multirow[t]{6}{*}{900} & 10 & $150.62^{\mathrm{b}} \pm 4.33$ & $49^{\mathrm{h}} \pm 2.71$ & $2.1^{c} \pm 0.02$ \\
\hline & & 30 & $170.87^{\mathrm{a}} \pm 6.10$ & $100^{f} \pm 8.55$ & $2.2^{\mathrm{c}} \pm 0.08$ \\
\hline & & 50 & $148.75^{\mathrm{b}} \pm 7.12$ & $148^{\mathrm{d}} \pm 3.09$ & $2.45^{\mathrm{b}} \pm 0.06$ \\
\hline & & 70 & $141.95^{\mathrm{c}} \pm 2.75$ & $177^{\mathrm{a}} \pm 1.44$ & $3.2^{\mathrm{a}} \pm 0.01$ \\
\hline & & 90 & $136.5^{\mathrm{d}} \pm 4.11$ & $138^{\mathrm{e}} \pm 9.12$ & $2.9^{\mathrm{ab}} \pm 0.01$ \\
\hline & & 100 & $124.09^{\mathrm{e}} \pm 1.15$ & $121^{\mathrm{e}} \pm 3.29$ & $0.6^{\mathrm{fg}} \pm 0.05$ \\
\hline
\end{tabular}

Each value is mean of five replicate with standard error (mean $\pm \mathrm{S}$. E). Means within a column not sharing a common superscript differ significantly $(\mathrm{P}<0.05)$ according to Duncan's new multiple range test 
Table 4. Estimation of phytochemical in soxhlet extracts of Cassia occidentalis L.

\begin{tabular}{|c|c|c|c|c|}
\hline $\begin{array}{l}\text { Sr. } \\
\text { No. }\end{array}$ & $\begin{array}{c}\text { Time of } \\
\text { extraction } \\
\text { (Hours) }\end{array}$ & $\begin{array}{c}\text { Phenolics } \\
\text { ( } \mu \text { g equivalent of } \\
\text { Gallic acid) }\end{array}$ & $\begin{array}{c}\text { Flavonoids } \\
\text { (ug equivalent of } \\
\text { Catechin) }\end{array}$ & $\begin{array}{c}\text { Alkaloids } \\
\text { (mg equivalent of } \\
\text { Dragondroff reagent) }\end{array}$ \\
\hline 1 & 5 & $55.12^{\mathrm{d}} \pm 2.56$ & $102^{\mathrm{c}} \pm 4.44$ & $0.6^{\mathrm{d}} \pm 0.04$ \\
\hline 2 & 10 & $91.25^{\mathrm{b}} \pm 2.90$ & $120^{\mathrm{a}} \pm 3.92$ & $1.45^{\mathrm{b}} \pm 0.01$ \\
\hline 3 & 15 & $96.75^{\mathrm{a}} \pm 0.09$ & $110^{\mathrm{b}} \pm 8.20$ & $1.55^{\mathrm{a}} \pm 0.09$ \\
\hline 4 & 20 & $84.75^{\mathrm{c}} \pm 3.33$ & $80^{\mathrm{d}} \pm 4.32$ & $1.1^{c} \pm 0.013$ \\
\hline
\end{tabular}

Each value is mean of five replicate with standard error (mean $\pm \mathrm{S}$. E). Means within a column not sharing a common superscript differ significantly $(\mathrm{P}<0.05)$ according to Duncan's new multiple range test

Phenolics are the key bioactive compounds isolated from medicinal plants. Plant polyphenols have prominent antimutagenic activity due to their antioxidant potential [23]. Rafiee et al., 2011 used microwave assisted extraction to isolate the phenolics from leaves of Olive and also made a comparison with maceration. They found the result at end that in all respects and for all parameters, microwave assisted extraction was the better choice for extraction of phenolics [24]. The extraction from microwave assisted extraction was of low cost and had high quality extraction rate. Victorioet al., 2009 separated flavonoids from leaves of Alpini azerumbet Pers. by using different extraction techniques such as maceration, soxhlet, microwave assisted extraction and ultrasonic extraction. They used ethanol and distill water were used for detection of flavonoids. Results showed rapid and maximum yield of flavonoids as compared to other methods of extraction [25]. Moreover ethanol is a polar solvent. As microwave assisted extraction depends on the dielectric susceptibility of solvent and matrix, better recoveries can be there by using polar solvents with high dielectric constant. But very dry samples as well as very wet samples with non-polar solvents like n-hexane decrease the efficiency of microwave assisted extraction. Non-polar solvents usually do not respond to the microwaves due to their lower dielectric constant and dissipation factor in comparison to the polar solvents, so no heat is transferred and no or a very little extraction goes on there. Water has a higher dielectric constant but it is sometimes so rapidly heated in microwaves that it destroys the chemical structure of compounds. No doubt there is a clear relationship between the chemical structure and the stability of phenolic compounds in solvents, so it also affects the efficacy of microwave assisted extraction depending on the plant source used. Microwave-assisted extraction may also be comparable to other modern extraction techniques such as supercritical fluid extraction due to its process simplicity and low cost [26, 27].

\section{Conclusion}

It was concluded from present studythat Microwave assisted extraction is a rapid, efficient, cost effective and reliable method of extraction for the extraction of phenolics, alkaloids and flavonoids from Cassia occidentalis. This method can be feasibly suggested to local herbal industry for cost effective and efficient extraction of phytoconstituents of Cassia occidentalis. 


\section{Authors' contributions}

Conceived and designed the experiments: $S$ Javad. Performed the experiments: S Younis. Analyzed the data: S Shaheen. Contributed reagents/materials/analyses tools: $\mathrm{F}$ Khan. Wrote the paper: S Javad.

\section{References}

1. Zampini IC, Cuello S, Alberto MR, Ordonez RM, Almeida RD, Solorzano E \& Isla MI (2009). Antimicrobial activity of selected plant species from Argentine puna against sensitive and multiresistant bacteria. J of Ethnopharmacology 124: 499-450.

2. Byarugaba DK (2004). A view on antimicrobial resistance in developing countries and responsible risk factors. Int $J$ of Antimicrob Agents 24: 105-110.

3. Dzidic S, Suskovic J \& Kos B (2008). Antibiotic resistance mechanisms in bacteria biochemical and genetic aspects. Food Tech and Biotech 46(1): 11-21.

4. Begum AT \& Anbazhakan S (2013). Evaluation of antibacterial activity of the mucilage of Dioscorea esculenta (Lour.) Burkill. Int J of Modern Biol and Med 4(3): 140-146.

5. Hassan BAR (2012). Medicinal Plants (importance and uses). Pharm Anal Acta 3(10): 4-6.

6. Shinwari ZK (2010). Medicinal plants research in Pakistan. $J$ of Med Plant Res 4(3): 161-176.

7. Khan B, Abdukadir A, Qureshi R \& Mustafa G (2011). Medicinal uses of plants by the inhabitants of Khunjerab National park, Gilgit, Pakistan. Pak J of Bot 43(5): 2301-2310.

8. Vashishtha VM, John TJ \& Kumar A (2009). Clinical and pathological features of acute toxicity due to Cassia occidentalis in vertebrates. Ind $\mathrm{J}$ of Med Res 130: 23-30.

9. Sini KR, Sinha BN, Karpakavalli Microwaves \& Sangeetha PT (2011).
Analgesic and antipyretic activity of Cassia occidentalis Linn. Annals of Biol Res 2(1): 195-200.

10. Mandal V, Mohan $\mathrm{Y}$ \& Hemalatha $\mathrm{S}$ (2007). Microwave assisted extraction an innovative and promising extraction tool for medicinal plant research. Pharmacognosy Rev 1(1): 7-8.

11. Chen L, Jin H, Ding L, Zhang H, Li J \& Qu C (2008). Dynamic microwave assisted extraction of flavonoids from Herbaepimedii. Separation and Purification Tech 59: 50-57.

12. Nasir A \& Ali SI (1982). Flora of Pakistan. Department of Botany, University of Karachi, Pakistan.

13. Saldanha CJ \& Nicolson DH (1976). Flora of Hassan District, Karnataka, India.

14. Arabshahi S \& Urooj A (2007). Antioxidant properties of various solvent extracts of mulberry (Morus indica L.) leaves. Food Chem102: 1233-1240.

15. Weirong $\mathrm{C}$, Xiaohong GU \& Tang $\mathrm{J}$ (2010). Extraction, purification, and characterization of the flavonoids from Opuntia milpa altaskin. Czech J of Food Sci 28(2): 108-116.

16. Shyaula SL, Ngakushi AB, Maharjan BL \& Manadhar MD. (2012). Estimation of Alkaloids and antibacterial activity of Aconitum spicatum. BruhlStap from Manaslu conservation area. Ind $J$ of agricult 13(1): 67-71.

17. Jaitak V, Singh BB \& Kaul VK (2009). An efficient microwave-assisted extraction process of stevioside and rebaudioside A from Stevia rebaudiana (Bertoni). Phytochem analysis 20(3): 240-5.

18. Javad S, Shagufta N, Saiqa I, Amna T \& Farah A (2014). Optimization of the Microwave assisted extraction and its comparison with different conventional extraction methods for isolation of 
stevioside from Stevia rebaudiana. Asian J of Chem 26(23): 8043-8048.

19. Mandal V, Mohan Y \& Hemalatha S (2008). Microwave assisted extraction of curcumin by sample-solvent dual heating mechanism using Taguchi L9 orthogonal design. $J$ Pharmaceutical Biomed 46: 322-327.

20. Shu YY, Ko MY \& Chang YS (2003). Microwave-assisted extraction of ginsenosides from ginseng root. $J$ of Microchemical 74: 131-139.

21. Zhang Z, Lv G, Pan H, Shi L \& Fan L (2011). Optimization of the microwaveassisted extraction process for polysaccharides in himematsutake (Agaricus blazei Murrill) and evaluation of their antioxidant activities. $J$ of Food Sci and Tech 17: 461-470.

22. Asghari J, Ondruschka B \& Mazaheritehrani M (2011). Extraction of bioactive chemical compounds from the medicinal Asian plants by microwave irradiation. $J$ of Med Plants 5(4): 495506.
23. Dai J \& Mumper RJ (2010). Plant phenolics: extraction, analysis and their antioxidant and anticancer properties. Molecules 15: 7313-7352

24. Rafiee Z, Jafari SM, Alami Microwaves \& Khomeiri M (2011). Microwaveassisted extraction of phenolic compounds from olive leaves; a comparison with maceration. The $J$ of Ani \& Plant Sci 21(4): 738-745.

25. Victorio CP, Lage CLS \& Kuster RM (2009). Flavonoid extraction from Alpinia zerumbet (Pers.) Burttet Smith leaves using different techniques and solvents. Ecletica Quimica 34(1): 19-24.

26. Liazid A, Guerrero RF, Cantos E, Palma Microwaves \& Barroso CG. (2011). Microwave assisted extraction of anthocyanins from grape skins. Food Chem 124(3), 1238-1243.

27. Kaufmann B, Christen P \& Veuthey J (2001) Parameters affecting microwave assisted extraction of withanolides. Phytochem Ana 12: 327-331. 